\title{
Immunotherapy-based combination strategies for treatment of gastrointestinal cancers: current status and future prospects
}

\author{
Chenfei Zhou, Jun Zhang $(\bowtie)$ \\ Department of Oncology, Ruijin Hospital Affiliated to Shanghai Jiao Tong University School of Medicine, Shanghai 200025, China \\ (C) The Author(s) 2019. This article is published with open access at link.springer.com and journal.hep.com.cn
}

\begin{abstract}
Strategies in comprehensive therapy for gastrointestinal (GI) cancer have been optimized in the last decades to improve patients' outcomes. However, treatment options remain limited for late-stage or refractory diseases. The efficacy of immune checkpoint inhibitors (ICIs) for treatment of refractory GI cancer has been confirmed by randomized clinical trials. In 2017, pembrolizumab was approved by the US Food and Drug Administration as the first agent for treatment of metastatic solid tumors with mismatch repair deficiency, especially for colorectal cancer. Given the different mechanisms, oncologists have focused on determining whether ICIs-based combination strategies could achieve higher efficacy than conventional therapy alone in late-stage or even front-line treatment of GI cancer. This review discusses the current status of combining immune checkpoint inhibitors with molecular targeted therapy, chemotherapy, or radiotherapy in GI cancer in terms of mechanisms, safety, and efficacy to provide basis for future research.
\end{abstract}

Keywords gastrointestinal cancer; immune checkpoint inhibitor; combination therapy

\section{Introduction}

In the last decade, the incidence and mortality rates of cancers have increased in China. The number of cancerrelated deaths reached approximately 2814000 in China, making cancer as the leading cause of death [1]. Gastrointestinal (GI) cancers, including stomach, liver, colorectal, esophageal cancers, are the top five cancers with the highest incidence and mortality rates [2]. In China, a large proportion of newly diagnosed patients with GI cancer belong to cases with unresectable tumors or with distant metastasis [3-5]. Although multi-disciplinary treatment can improve treatment outcomes, management of patients with GI cancer and refractory diseases remains challenging [6,7].

The roles of host anti-tumor immunity against tumor development and progression have been widely investigated to understand the interaction between tumor cells and the host immune system. Immunotherapy, which aims to mobilize the host immune system against tumor cells, is a promising strategy for treatment of patients with cancer

Received June 24, 2018; accepted December 27, 2018

Correspondence: Jun Zhang, junzhang@188.com
[8-11]. Since the emergence of immune checkpoint inhibitors (ICIs), immunotherapy has been widely used in clinical practice, particularly for treatment of solid tumors [12]. At present, ICIs, such as cytotoxic Tlymphocyte-associated protein 4 (CTLA-4, CD152) antibody (ipilimumab), programmed cell death 1 protein (PD1, CD279) antibodies (nivolumab and pembrolizumab), and PD-1 ligand 1 (PD-L1, CD274) antibodies (atezolizumab, avelumab, and durvalumab) are approved by the US Food and Drug Administration. The efficacy of these inhibitors has been demonstrated in melanoma, lung cancer, renal cell carcinoma, bladder cancer, and colorectal cancer. ICIs have become one of the pillars of comprehensive cancer treatment [13-16].

Although predictive biomarkers, such as mismatch repair deficiency, tumor mutation burden, and PD-L1 expression, have been used to enrich patients who will probably benefit from ICIs, the fraction of patients with GI cancer who will acquire durable clinical response remains limited. The response rates to ICI monotherapy are approximately 5\%-30\% in gastroesophageal cancer, $10 \%-20 \%$ in hepatobiliary cancer, and $30 \%-50 \%$ in colorectal cancer with mismatch repair deficiency; meanwhile, the therapy has no clinical benefit in pancreatic cancer [16-21]. In this regard, strategies to optimize the 
clinical application of ICIs should be further investigated [22].

Conventional therapies, including molecular targeted therapy, chemotherapy, and radiation, can modulate the host anti-tumor immunity and exert possible synergistic effect with ICIs [23]. Scholars have attempted to combine ICIs with conventional therapies for GI cancer through early-stage clinical trials (Table 1). Numerous trials are underway to assess the efficacy of such combination (Table 2). In the present work, we aim to review current evidence of combining ICIs with molecular targeted therapy, chemotherapy, or radiotherapy for treatment of GI cancer.

\section{Status of tumor immunity and immune checkpoint blockade}

Tumor-immunity cycle derived by innate and adaptive immune systems should be completed to initiate anti-tumor immune responses and protect against tumor cells [24]. Immune cells, including antigen presenting cells (APC), natural killer (NK) cells, and cancer-specific cytotoxic $\mathrm{T}$ cells, in the tumor microenvironment participate in regulating anti-tumor immune responses. Tumor antigenloaded dendritic cells migrate into lymphoid organs to prime naïve $\mathrm{CD}^{+} \mathrm{T}$ cells and promote the activation of NK cells. The recognition of class I major histocompatibility complex (MHC) by T-cell receptor (TCR) and CD8 and the interaction of B7 and CD28, known as costimulatory signals, are necessary to prime naïve $\mathrm{CD} 8^{+} \mathrm{T}$ cells into cytotoxic $\mathrm{T}$ cells. The activated cancer-specific $\mathrm{T}$ cells then destroy the tumor cells by releasing cytotoxins and expressing FAS ligands [25].

The tumor cells will finally acquire immune escape and grow into macroscopic neoplasms due to immunoediting [26]. Genetic and epigenetic changes in the tumor cells with the immunosuppressive microenvironment

Table 1 Current data on combining ICIs with other therapies for GI cancer

\begin{tabular}{|c|c|c|c|c|c|c|}
\hline Trial & Phase & Line & Treatment & No. & Efficacy & Adverse events \\
\hline \multicolumn{7}{|l|}{ Anti-angiogenesis agents } \\
\hline \multicolumn{7}{|l|}{ Colorectal cancer } \\
\hline Abstract $2651[55]$ & 2 & $1 \mathrm{st}$ & $\mathrm{B}+\mathrm{A}+\mathrm{FOLFOX}$ & 23 & $\begin{array}{l}\text { ORR } 52 \% \\
\text { PFS } 14.1 \mathrm{~m} \text {, DOR } 11.4 \mathrm{~m}\end{array}$ & NR \\
\hline NCT01633970 [54] & $1 \mathrm{~b}$ & $\geqslant 3 \mathrm{rd}, \mathrm{dMMR}$ & $\mathrm{B}+\mathrm{A}$ & 10 & ORR $30 \%$ & G3/4 40\%; all-grade $80 \%$ \\
\hline \multicolumn{7}{|l|}{ Gastric cancer } \\
\hline NCT02999295 & $1 / 2$ & 2nd & $\mathrm{Ram}+\mathrm{N}$ & 46 & PR $22 \%$, DCR $59 \%$ & G3/4 13\%; all-grade $87 \%$ \\
\hline NCT02572687 [58] & $1 \mathrm{a} / \mathrm{b}$ & $\geqslant 2$ nd & Ram + D & 29 & $\begin{array}{l}\text { ORR } 17 \% \\
\text { PFS } 2.6 \mathrm{~m} \text {, OS } 6.4 \mathrm{~m}\end{array}$ & G3/4 72\%; all-grade $100 \%$ \\
\hline \multicolumn{7}{|l|}{ Hepatocellular cancer } \\
\hline NCT03006926 [59] & $1 b$ & $1 \mathrm{st}$ & $\mathrm{L}+\mathrm{P}$ & 18 & PR $46 \%$, SD $46 \%$ & All-grade $94 \%$ \\
\hline NCT02715531 [60] & $1 \mathrm{~b}$ & $1 \mathrm{st}$ & $\mathrm{B}+\mathrm{A}$ & 26 & PR $62 \%$ & G3/4 35\%; all-grade $81 \%$ \\
\hline \multicolumn{7}{|l|}{ Other targeted agents } \\
\hline \multicolumn{7}{|l|}{ Colorectal cancer } \\
\hline NCT02437136 [72] & 2 & $\geqslant 2$ nd & Entinostat $+\mathrm{P}$ & 16 & $1 \mathrm{PR}, 5 \mathrm{SD}$ & G3/4 50\%; all-grade $100 \%$ \\
\hline NCT01988896 [73] & 1 & $\geqslant 3 \mathrm{rd}$ & $\mathrm{C}+\mathrm{A}$ & 23 & ORR $17 \%$ & G3/4 34.8\%; \\
\hline NCT02788279 [74] & 3 & $\geqslant 3$ rd & $\mathrm{C}+\mathrm{A} / \mathrm{A} / \mathrm{Reg}$ & 363 & $\begin{array}{l}\text { OS } 8.9 \mathrm{~m} / 7.1 \mathrm{~m} / 8.5 \mathrm{~m} \\
\text { ORR } 2.7 \% / 2.2 \% / 2.2 \%\end{array}$ & $\mathrm{G} 3 / 4$ 45\%/10\%/49\% \\
\hline \multicolumn{7}{|l|}{ Gastric cancer } \\
\hline NCT02689284 [69] & 2 & 2nd, HER2 (+) & $\mathrm{M}+\mathrm{P}$ & 60 & ORR $16 \%$, DCR $54 \%$ & G3/4 16\% \\
\hline \multicolumn{7}{|c|}{ Chemotherapy or radiotherapy } \\
\hline \multicolumn{7}{|l|}{ Colorectal cancer } \\
\hline Abstract $3541[11]$ & 2 & $1 \mathrm{st}$ & FOLFOX6 + P & 30 & $\begin{array}{l}\text { ORR } 53 \% \\
8 \text { w DCR } 100 \%\end{array}$ & $\mathrm{G} 3 / 436.7 \%$ \\
\hline NCT02437071 [85] & 2 & $\geqslant 3 \mathrm{rd}$ & Radiation/ablation $+\mathrm{P}$ & 19 & ORR 9\% & All-grade $73 \%$ \\
\hline \multicolumn{7}{|l|}{ Gastric cancer } \\
\hline $\begin{array}{l}\text { NCT02335411 } \\
\text { KEYNOTE-059 } \\
\text { Cohort } 2 \text { [83] }\end{array}$ & 2 & 1st, HER2 (-) & $\mathrm{CF}+\mathrm{P}$ & 25 & $\begin{array}{l}\text { ORR } 60 \% \\
\text { PFS } 6.6 \mathrm{~m} \\
\text { OS } 13.8 \mathrm{~m}\end{array}$ & $\mathrm{G} 3 / 476 \%$ \\
\hline
\end{tabular}

Abbreviations: A, atezolizumab; B, bevacizumab; C, cobimetinib; D, durvalumab; DCR, disease control rate; DOR, duration of response; G, grade; $\mathrm{L}$, lenvatinib; M, margetuximab; m, month; N, nivolumab; NR, not reported; ORR, objective response rate; OS, overall survival; PR, partial response; P, pembrolizumab; PFS, progression free survival; Ram, ramucirumab; Reg, regorafenib; SD, stable disease; w, week. 
Table 2 Ongoing clinical trials on combining ICIs with other therapies for GI cancer

\begin{tabular}{|c|c|c|c|c|}
\hline$\overline{\text { Trial }}$ & Phase & Patients & Treatment & End point \\
\hline \multicolumn{5}{|l|}{ Esophageal cancer } \\
\hline NCT03044613 & 2 & $\begin{array}{l}\text { Neoadjuvant } \\
\text { cStage II/III }\end{array}$ & $\begin{array}{l}\text { Nivolumab } \pm \text { ipilimumab followed by carboplatin }+ \text { paclitaxel }+ \text { RT }+ \\
\text { nivolumab }\end{array}$ & Safety \\
\hline NCT03377400 & 2 & 1st-line, SCC & Durvalumab or tremelimumab + CCRT & PFS \\
\hline NCT03437200 & 2 & 1st-line & $\begin{array}{l}\text { Arm A: chemoradiation + nivolumab } \\
\text { Arm B: chemoradiation }+ \text { nivolumab }+ \text { ipilimumab }\end{array}$ & $12 \mathrm{~m}$ PFS \\
\hline \multicolumn{5}{|l|}{ Gastric cancer } \\
\hline NCT03006705 & 3 & $\begin{array}{l}\text { Adjuvant } \\
\text { pStage III (D2) }\end{array}$ & $\begin{array}{l}\text { Arm A: nivolumab }+ \text { S-1 or CapeOX } \\
\text { Arm B: placebo }+ \text { S-1 or CapeOX }\end{array}$ & RFS \\
\hline $\begin{array}{l}\text { NCT03221426 } \\
\text { KEYNOTE-585 }\end{array}$ & 3 & Perioperative & $\begin{array}{l}\text { Arm A: pembrolizumab + XP; Arm B: placebo + XP } \\
\text { Arm C: pembrolizumab + FLOT; Arm D: placebo + FLOT }\end{array}$ & OS, pCR \\
\hline $\begin{array}{l}\text { NCT03382600 } \\
\text { KEYNOTE-659 }\end{array}$ & $2 b$ & 1st-line & $\begin{array}{l}\text { Arm A: pembrolizumab + oxaliplatin }+ \text { S-1 } \\
\text { Arm B: pembrolizumab + cisplatin }+ \text { S-1 }\end{array}$ & ORR \\
\hline NCT03488667 & 2 & Perioperative & Pembrolizumab + mFOLFOX 6 before and after surgery & ypRR \\
\hline NCT02918162 & 2 & Perioperative & $\begin{array}{l}\text { Chemotherapy }+ \text { pembrolizumab before and after surgery } \\
\text { Pembrolizumab maintenance }\end{array}$ & $24 \mathrm{~m} \mathrm{DFS}$ \\
\hline NCT03257163 & 2 & Perioperative & $\begin{array}{l}\text { Pembrolizumab before surgery } \\
\text { Pembrolizumab }+ \text { capecitabine after surgery }\end{array}$ & RFS \\
\hline NCT03409848 & 2 & 1st-line, HER2 (+) & $\begin{array}{l}\text { Arm A: trastuzumab + nivolumab + ipilimumab } \\
\text { Arm B: trastuzumab }+ \text { nivolumab }+ \text { mFOLFOX6 }\end{array}$ & OS \\
\hline NCT02872116 & & 1st-line & $\begin{array}{l}\text { Arm A: nivolumab + ipilimumab followed by nivolumab } \\
\text { Arm B: XELOX } \\
\text { Arm C: FOLFOX } \\
\text { Arm D: nivolumab + XELOX } \\
\text { Arm E: nivolumab + FOLFOX }\end{array}$ & $\begin{array}{l}\text { OS: } \\
\text { A vs. B }+ \text { C; } \\
\text { D + E vs. B + C }\end{array}$ \\
\hline NCT03342937 & 2 & 1st-line & Pembrolizumab + CapeOx & PFS \\
\hline NCT03413397 & 2 & $\geqslant 2$ nd-line & Pembrolizumab + lenvatinib & ORR \\
\hline NCT03453164 & $1 / 2$ & $\geqslant 2$ nd-line & Nivolumab + radiotherapy & DCR \\
\hline NCT02999295 & $1 / 2$ & $\geqslant 2$ nd-line & Nivolumab + ramucirumab & $6 \mathrm{~m}$ PFS \\
\hline \multicolumn{5}{|l|}{ Colorectal cancer } \\
\hline $\begin{array}{l}\text { NCT02563002 } \\
\text { KEYNOTE-177 }\end{array}$ & 3 & 1st-line, dMMR & $\begin{array}{l}\text { Arm A: pembrolizumab } \\
\text { Arm B: chemotherapy } \\
\text { Arm A: atezolizumab }\end{array}$ & PFS, OS \\
\hline NCT02788279 & 3 & $\geqslant 3$ rd-line & $\begin{array}{l}\text { Arm B: cobimetinib }+ \text { atezolizumab } \\
\text { Arm C: regorafenib }\end{array}$ & OS \\
\hline NCT03414983 & $2 / 3$ & 1st-line & $\begin{array}{l}\text { Arm A: nivolumab + FOLFOX }+ \text { bevacizumab } \\
\text { Arm B: FOLFOX }+ \text { bevacizumab }\end{array}$ & PFS \\
\hline NCT03174405 & 2 & 1st-line & Avelumab + cetuximab + FOLFOX & $12 \mathrm{~m}$ PFS \\
\hline NCT03202758 & $1 / 2$ & 1st-line, Kras MT & Durvalumab + tremelimumab + FOLFOX & Safety \\
\hline NCT03475004 & $1 / 2$ & 3rd-line & Pembrolizumab + bevacizumab + binimetinib & ORR \\
\hline NCT03332498 & $1 / 2$ & $>3$ rd-line & Pembrolizumab + ibrutinib & $4 \mathrm{~m} \mathrm{DCR}$ \\
\hline \multicolumn{5}{|l|}{ Hepatocellular cancer } \\
\hline NCT03434379 & 3 & 1st-line & $\begin{array}{l}\text { Atezolizumab }+ \text { bevacizumab } \\
\text { Sorafenib }\end{array}$ & ORR/OS \\
\hline NCT03439891 & 2 & 1st-line & Nivolumab + sorafenib & Safety/ORR \\
\hline NCT01658878 & $1 / 2$ & 1st-line & Nivolumab + cabozantinib & Safety/ORR \\
\hline NCT03382886 & 1 & $\geqslant 2$ nd-line & Nivolumab + bevacizumab & Safety \\
\hline \multicolumn{5}{|l|}{ Biliary tract cancer } \\
\hline NCT03101566 & 2 & 1st-line & $\begin{array}{l}\text { Nivolumab }+ \text { gemcitabine }+ \text { cisplatin } \\
\text { Nivolumab }+ \text { ipilimumab }\end{array}$ & $6 \mathrm{~m}$ PFS \\
\hline NCT03111732 & 2 & $\geqslant 2$ nd-line & Pembrolizumab + oxaliplatin + capecitabine & $5 \mathrm{~m}$ PFS \\
\hline
\end{tabular}




\begin{tabular}{rllll}
\hline & & & & \\
\hline Trial & Phase & Patients & Treatment & End point \\
\hline Pancreatic cancer & & & & \\
NCT02620423 & 1 & 2nd-line & Pembrolizumab + chemotherapy & Safety \\
NCT03250273 & 2 & $\geqslant 2$ nd-line & Nivolumab + entinostat & ORR \\
NCT02879318 & 2 & 1st-line & Tremelimumab + durvalumab + G + nab-paclitaxel & OS \\
& & & Gemcitabine + nab-paclitaxel & \\
\hline
\end{tabular}

modulated by the tumor cell itself result in immune escape. The low expression of class I MHC and B7 on tumor cells is the most common mechanism, and the high expression of PD-L1 causes the exhaustion of effector T cells. In tumor stroma, immunosuppressive molecules, such as transforming growth factor- $\beta$ (TGF $\beta$ ), indoleamine 2,3dioxygenase, arginase, and nitric oxide synthase, released by tumor cells can form the immunosuppressive microenvironment $[27,28]$. TGF $\beta$ can induce immune escape by promoting the exclusion of $\mathrm{T}$ cells and blocking the acquisition of the Th1 effector phenotype [29,30]. Regulatory $\mathrm{T}$ cells (Tregs), which can suppress the activation of effector $\mathrm{T}$ cells, are usually recruited into the tumor stroma. Chemokines produced by tumor cells, such as CCL22, can promote Tregs infiltration by activating CCR4 [31]. Intratumoral hypoxia can also suppress the activation of effector T cells [32].

Immune checkpoints, namely, CTLA-4, PD-1, and PD$\mathrm{L} 1$, have been identified as favorable targets to reverse tumor immune escape. CTLA-4, which is upregulated on activated T cells, competes with CD28 to bind to B7 and then transduces the inhibitory signal into $\mathrm{T}$ cells. Therefore, the persistent activation of effector $\mathrm{T}$ cells can be maintained by targeting CTLA-4. CTLA-4 inhibition can also enhance naïve $T$ cell priming in lymphoid organs and deplete Tregs in the tumor microenvironment $[33,34]$. The PD-1/PD-L1 pathway is another inhibitory signal of effector T cell and inhibits TCR-mediated T cell activation and proliferation, resulting in $\mathrm{T}$ cell exhaustion and apoptosis. Upregulation of PD-L1 is commonly detected on tumor cells and Tregs in the tumor microenvironment. Therefore, inhibiting the PD-1/PD-L1 pathway mainly overcomes immune escape in the tumor microenvironment [35].

\section{Combination with anti-angiogenesis targeted therapy}

The vascular endothelial growth factor (VEGF) pathway promotes tumor angiogenesis and plays a critical role in tumor development and progression [36]. The suppressive effect of VEGF on host anti-tumor immune response has been recognized [37,38]. (1) VEGF can interfere with the maturation of DCs and effector T cells and inhibit the function of cytotoxic T cells [39]. (2) Overexpression of VEGF can promote the intratumoral accumulation, differentiation, and proliferation of Tregs [40,41]. (3) Accumulation of myeloid-derived suppressor cells, which inhibit tumor-directed $\mathrm{T}$ cell response, is regulated by the VEGF pathway [42]. Immature myeloid cells, which impede the maturation of DCs, are also recruited by VEGF into the tumor microenvironment $[43,44]$. (4) VEGF suppresses the expression of endothelial intercellular adhesion molecule-1 on endothelium cells and interferes with the trafficking of antitumor effector $\mathrm{T}$ cells by inhibiting cell adhesion [39]. (5) The abnormal anatomy and function of intratumoral vessels induced by VEGF can also suppress the infiltration of effector $T$ cells [45,46] (Fig. 1).

Molecular agents (such as monoclonal antibodies and tyrosine kinase inhibitors), which target the VEGF pathway, have been administered in clinical practices for treatment of GI cancer. The efficacy of bevacizumab, an anti-VEGF antibody, has been demonstrated in metastatic colorectal cancer (mCRC) [47]. The multi-targeted tyrosine kinase inhibitor (TKI) regorafenib targeting VEGFR2 has been approved for treatment of refractory colorectal cancer [48]. Sorafenib is used as the standard first-line therapy for advanced or metastatic hepatocellular cancer (HCC) [49]. Other TKIs targeting VEGFRs, including lenvatinib and cabozantinib, can also be used to treat patients with HCC [50]. Ramucirumab, a fully human monoclonal antibody targeting VEGFR2, has been approved as second-line regime, monotherapy or combination with paclitaxel for treatment of advanced gastric cancer [51].

In pre-clinical investigation, the combination of bevacizumab with atezolizumab, an anti-PD-L1 antibody, increased the infiltration of intra-tumoral $\mathrm{CD} 8^{+} \mathrm{T}$ cells into the xenografts of renal cell carcinoma. Increased CX3CR1 was observed on peripheral $\mathrm{CD} 8^{+} \mathrm{T}$ cell, which suggested that the combined therapy could improve the migration of $T$ cells [37]. Bevacizumab could also enhance the presentation of tumor antigens in breast, lung, and colorectal cancer. VEGFR2 inhibitors showed synergic effect with anti-PD-1 antibodies on inhibiting the tumor growth of colon cancer cell lines in vivo, but they did not 


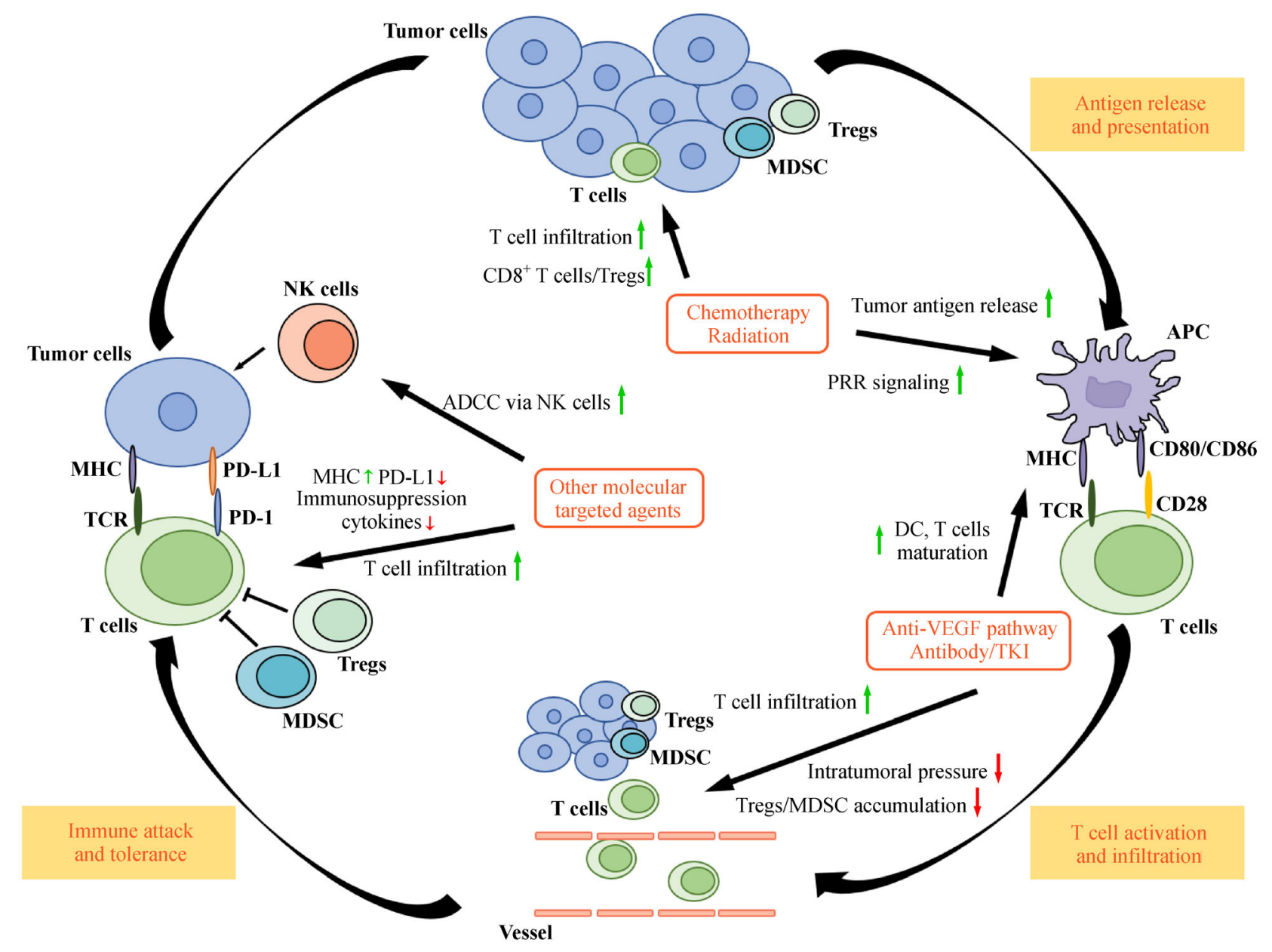

Fig. 1 Mechanisms of ICI interaction with conventional therapies against tumor cells.

interfere with $\mathrm{T}$ cell infiltration and activation [52]. Moreover, normalization of the function and anatomy of tumor vessels after anti-angiogenesis therapy could facilitate the infiltration of immune cells into tumor lesion, thereby enhancing the effect of immune checkpoint inhibition [46,53].

A phase Ib study (NCT01633970) evaluated the combination of bevacizumab and atezolizumab in MSIhigh mCRC patients as rescue therapy. Ten patients were enrolled. The confirmed overall response rate (ORR) was $30 \%$ with a median follow-up of 11.1 month, and the overall survival (OS) was not reached. Grade 3 proteinuria was observed in 1 patient (10\%) [54]. In another phase $\mathrm{Ib}$ study, atezolizumab was combined with FOLFOX plus bevacizumab as first-line treatment for mCRC patients. A total of 23 patients were enrolled, and ORR was 52\% with a median progression-free survival (PFS) of 14.1 months and median duration of response (DOR) of 11.4 months. Biomarkers analysis showed that patients with increased $\mathrm{CD}^{+} \mathrm{T}$ cell infiltration and expression of cytotoxic $\mathrm{T}$ cell signatures had prolonged disease control duration [55]. In comparison with the results of NO16966 trial (FOLFOX plus bevacizumab: ORR 38\%, PFS 9.4 months) [56], the addition of atezolizumab might improve the efficacy of FOLFOX plus bevacizumab.

For gastric cancer, a phase Ia/b study (JVDF trial, NCT02572687) reported the combination of ramucirumab $(8 \mathrm{mg} / \mathrm{kg})$ with durvalumab $(750 \mathrm{mg})$ in treating 29 advanced gastric or gastro-esophageal junction adenocarcinoma patients who previously received at least one line of chemotherapy. Confirmed partial response (PR) was 17\% (5/29). Median PFS was 2.6 months, and OS was 6.4 months [57,58]. Another phase $1 / 2$ study (NCT02999295) evaluated the combination of ramucirumab $(8 \mathrm{mg} / \mathrm{kg})$ with nivolumab (3 $\mathrm{mg} / \mathrm{kg}$, every 2 weeks) as second-line therapy. A total of 46 patients were enrolled. PR was $22 \%(10 / 46)$, and disease control rate (DCR) was $59 \%$. For ramucirumab monotherapy as second-line treatment for gastric cancer, the ORR was only $2.9 \%$. Median PFS and OS were 2.1 and 5.2 months, respectively [51]. Results indicated that the efficacy of the combination of ramucirumab with ICI was better than monotherapy. More data 
should be obtained from future randomized controlled clinical trials.

For hepatocellular cancer, anti-VEGFR TKI is one of the major choices for patients in advanced stage, but the efficacy of its combination with ICIs is still unclear. Clinical trials evaluating the combination of sorafenib, lenvatinib, axitinib, cabozantinib, or regorafenib with nivolumab, pembrolizumab, or avelumab are now ongoing. The preliminary result from a phase $\mathrm{Ib}$ trial (NCT03006926) evaluating lenvatinib (8-12 mg daily) plus pembrolizumab (200 mg, ever 3 weeks) as first-line therapy for unresectable $\mathrm{HCC}$ patients (BCLC stage $\mathrm{B} / \mathrm{C}$, Child-Pugh class A) showed that both $\mathrm{PR}$ and stable disease (SD) were $46 \%(6 / 13)$ in 13 evaluable patients. Most common adverse events were decreased appetite and hypertension (56\% each, all grade) [59]. Bevacizumab $(15 \mathrm{mg} / \mathrm{kg})$ plus atezolizumab (1200 mg) was administrated every three weeks as first-line treatment for the chemotherapy naïve unresectable or metastatic HCC patients in a phase Ib study (NCT02715531). A total of 26 patients were enrolled. For 21 efficacy-evaluable patients, the PR was $62 \%$ (13/22). Hypertension was observed in 19\% patients (all grade) [60]. According to the promising result, a multicenter, open-label, and randomized phase III trial of bevacizumab plus atezolizumab versus sorafenib in advanced HCC is now ongoing (NCT03434379).

\section{Combination with other targeted agents}

Anti-ERBB family antibodies comprise another important type of targeted agents, which have been widely used in clinical practices for GI cancer. Aside from directly inhibiting important signal pathways, which control proliferation, anti-apoptosis, and invasion of tumor cells, recombinant antibodies can also induce host anti-tumor immune response through antibody-dependent cell-cytotoxicity (ADCC), antibody-dependent cell-phagocytosis and complement-dependent cytotoxicity [61]. The identification of the immunoglobulin G1 (IgG1) backbone of antibodies, such as cetuximab and trastuzumab, is necessary to mobilize immune responses [62].

The immune modulation of cetuximab has been widely investigated (Fig. 1). In comparison with chemotherapy alone, immune cell infiltration $\left(\mathrm{CD}^{+}, \mathrm{CD}^{+}\right.$, and $\left.\mathrm{CD} 56^{+}\right)$ into liver metastatic sites was increased after treatment with cetuximab plus chemotherapy in colorectal cancer [63]. Cetuximab can also induce ADCC via NK cells and increase the HLA class I molecule expression on tumor cells [64]. Activated NK cells can kill tumor cells to release tumor antigens, which are presented by DCs to prime effector T cell. NK cells can also directly interact and improve the function of other immune cells, including DCs and macrophages [62]. Therefore, cetuximab can modulate both innate immune response and adoptive immune system. However, a bidirectional effect of cetuximab on immune response was also noticed. The activation of the immunosuppressive pathway as a feedback mechanism was observed after cetuximab administration. Cetuximab could enhance Tregs infiltration and trigger PD-L1 expression on tumor cells, which exhausted the effector $\mathrm{T}$ cells $[65,66]$. Some of these phenomena could also be observed after treatment with trastuzumab. In breast cancer, increased tumor-infiltrating lymphocytes was associated with the efficacy of trastuzumab-based treatment, while PD-L1 was upregulated in tumor cells, which resisted trastuzumab $[67,68]$. Considering their bidirectional effect on anti-tumor immunity, immune checkpoint inhibitors may reverse the immunosuppressive effect of anti-ERBB antibodies by unleashing the function of effector $\mathrm{T}$ cells and impeding Tregs activation.

The efficacy of anti-ERBB antibodies plus ICIs is still under investigation in GI cancer. A phase II clinical trial (NCT03409848) for gastric cancer is now ongoing to assess the efficacy of trastuzumab combined with nivolumab plus mFOLFOX6 (Table 2). The combination of margetuximab, a novel anti-HER2 monoclonal antibody, with pembrolizumab was administrated in HER2-amplified and PD-L1 positive gastroesophageal adenocarcinoma patients as second-line therapy after trastuzumab progression in a phase II trial (NCT02689284). A total of 60 patients were enrolled. ORR was $16 \%$, and DCR was $54 \%$ in 57 evaluable patients. Notably, for patients with HER2 amplification and PD-L1 positivity by circulating tumor DNA (ctDNA) detection, ORR was 57\% and DCR was $86 \%$. Treatment-related adverse events (TRAEs, $\geqslant$ grade 3 ) occurred in $13 \%$ of the patients, and serious adverse events (SAEs) included autoimmune hepatitis (two cases) and pneumonitis (one case) [69] (Table 1).

For other molecular targeted agents, including smallmolecule kinase inhibitors and epigenetic modulators, immune sensitization is mainly modulated by the regulating expression of immune molecules [70] (Fig. 1). BRAF inhibitors increased expression of MHC class I molecules. EGFR kinase and mTOR inhibitors can decrease the transcription of PD-L1 and inhibit the function of FOXP3 ${ }^{+}$ Tregs. Epigenetic modulators such as histone deacetylase inhibitors and methylation inhibitors can increase the expression of NK-cell-activating ligands, MHC class I and II molecules, and proinflammatory cytokines. MEK inhibitors decrease the immunosuppressive cytokine expression (IL-1, IL-6, IL-8, IL-10, and VEGF) in tumor microenvironment [71]. Oral class I-selective histone deacetylase inhibitor entinostat (5 $\mathrm{mg}$, daily) plus pembrolizumab (200 $\mathrm{mg}$, every 3 weeks) was used to treat mCRC patients with pMMR (NCT02437136). In total 16 patients, a patient acquired PR, and five patients had SD. Common TRAEs include fatigue (37.5\%), arthralgia (18.8\%), and increased alkaline phosphatase (18.8\%) [72]. The efficacy of MEK inhibitor cobimetinib plus 
atezolizumab was evaluated in a phase I trial. A total of 23 mCRC patients were enrolled and cobimetinib was provided with incremental dosage. The ORR was $17 \%$ (4PR, 5SD). Notably, three out of four patients with PR had mismatched repair proficiency (pMMR) [73]. However, the efficacy of cobimetinib plus atezolizumab was not validated by phase III trial. In IMblaze 370 trial (NCT02788279), mCRC patients with pMMR were randomized at 2:1:1 ratio to receive atezolizumab plus cobimetinib, atezolizumab monotherapy, or regorafenib. Results showed that the median OS among the three groups did not significantly differ ( 8.9 months vs. 7.1 months vs. 8.5 months), as well as PFS and ORR. Therefore, IMblaze 370 trial did not meet its primary endpoint. Grade 3/4 TRAEs rate was $45 \%$ in the atezolizumab plus cobimetinib group, and common TRAEs included diarrhea (56\%), rash (42\%), and nausea (32\%) [74].

\section{Combination with chemotherapy or radiotherapy}

Chemotherapy and radiotherapy both directly execute nonspecific anti-tumor activity on tumor cells by inhibiting cell mitosis and inducing cell apoptosis. Tumor antigens from killed tumor cells can be presented by APCs and can create a polyvalent tumor cell vaccine in situ. Then, a cascade of promoting adaptive antigen-specific immune response will be set off. Therefore, chemotherapy and radiotherapy can mobilize host anti-tumor immune response [75]. Chemotherapy and radiotherapy also regulate the immune system directly. The expression of class I MHC molecule and PD-L1 on tumor cells can be increased during genotoxic treatment [76,77]. The immunosuppressive architecture of tumor microenvironment is also distorted by chemotherapy and radiation, thereby facilitating infiltration of immune cell and transfection of drugs. Enhanced $\mathrm{CD}_{4} 5^{+} \mathrm{CD}^{+} \mathrm{T}$ cells, reduced $\mathrm{CD} 11 \mathrm{~b}^{+} \mathrm{Gr}^{+}$ myeloid cells infiltration, and increased ratio of $\mathrm{CD} 8^{+} \mathrm{T}$ cells to Tregs can be observed after chemotherapy and radiotherapy [78] (Fig.1).

The mechanisms of genotoxic therapies, which modulate immunogenic effects, are mainly mediated by enhancing the pattern recognition receptor (PRR) signaling upon recognizing tumor antigens, which is known as immune adjuvanticity [71]. The principle assault of chemotherapy and radiotherapy is on cellular DNA, which causes genomic integrity disruption, DNA double strand break, DNA cross-links, and other chromosomal abnormalities. Damage-associated molecular pattern molecules (DAMPs) including adenosine triphosphate (ATP) and high mobility group box 1 (HMGB1) protein are released by dying and stressed cells. Toll-like receptors, the major type of PRR on innate immune cells, can be activated by binding with DAMPs. The activation of innate immunity then stimulates DC maturation, antigen presentation, and type I IFN production [79].

The clinical efficacy of combining ICI with chemotherapy has been demonstrated in non-small cell lung cancer (NSCLC). A meta-analysis reported that the ORR and DCR for combination of ICI with chemotherapy were $47.0 \%$ and $80.9 \%$, respectively [80,81]. In KEYNOTE189 trial, a phase 3, double-blind, placebo-controlled randomized trial assessed the pemetrexed and platinumbased chemotherapy plus either pembrolizumab or placebo as first-line therapy for non-squamous NSCLC patients without sensitizing EGFR or ALK mutations. Results showed that both PFS (8.8 months vs. 4.9 months, HR $0.52,95 \%$ CI $0.43-0.64, P<0.001)$ and OS rate at 12 months $(69.2 \%$ vs. $49.4 \%$, HR 0.49 , 95\%CI $0.38-0.64$, $P<0.001)$ were improved by combination with pembrolizumab [82].

In gastric cancer, KEYNOTE-059 trial cohort 2 (NCT02335411) evaluated the efficacy of pembrolizumab plus cisplatin and fluoropyrimidine regime as first-line treatment for HER2-negative patients [83]. Results showed that in 25 patients, the ORR was $60 \%$ (PD-L1 positive $68.8 \%$, PD-L1 negative $37.5 \%$ ) with PFS of 6.6 months and OS of 13.8 months. Grade 3/4 TRAEs occurred in $76 \%$ of the patients. In comparison with the results of KEYNOTE-059 cohort 3 (pembrolizumab as first-line therapy for PD-L1-positive gastric cancer patients), the ORR of pembrolizumab monotherapy was $26.0 \%$ (CR $7 \%$ ), while the median OS was 20.7 months [57]. Results indicated that a relative increased ORR of the combined therapy did not achieve a survival benefit of advanced gastric cancer patients. For colorectal cancer, pembrolizumab plus FOLFOX6 was employed as first-line treatment in 30 patients. The ORR was $53 \%$, and the 8 -week DCR was $100 \%$. Adverse events could be tolerated with grade $3 / 4$ AE of $36.7 \%$ [11] (Table 2).

Preoperative or adjuvant radiotherapy is now administrated to treat gastroesophageal cancer and rectal cancer, whereas palliative radiation for advanced or metastatic GI cancer is often used as part of the comprehensive treatment to control cancer-related symptoms and improve the quality of life. Based on several studies with small sample size, local radiation could cause tumor shrinking outside the scope, which was known as the abscopal effect [84]. Mechanisms of abscopal effect might be mediated by mobilizing anti-tumor immune response. The host adaptive immunity can be activated by radiation, including NK cell mobilization, $\mathrm{CD}^{+} \mathrm{T}$ cell infiltration, antigen presentation of DCs, and upregulation of immunostimulatory cytokines, which can kill tumor cells outside the target lesion of radiation. Therefore, immune checkpoint inhibition can play a synergistic role with radiotherapy by promoting systemic immune response in host environment [85]. In NSCLC, a retrospective study compared the efficacy of hypo-fractionated radiation plus nivolumab and nivolumab 
monotherapy. For a total 35 pretreated patients, 15 patients received combination therapy. The one-year OS $(57.8 \%$ vs $27.4 \%, P=0.043)$ and PFS rates $(57.8 \%$ vs. $20.6 \%, P=$ 0.040 ) were both relative higher in the combination group [86].

In a phase II trial, mCRC patients who had progressed after two or more standard regimes were treated with pembrolizumab plus radiotherapy or ablation. Primary results showed that ORR was $9 \%$ in 19 cases, while the rate of adverse events with any grade was 73\% (NCT02437071) [85]. Currently, the efficacy of radiotherapy combined with ICIs has not been demonstrated by perspective clinical trials in GI cancer. For esophageal cancer, several clinical trials, which evaluate the combination of chemoradiotherapy with ICIs as neoadjuvant or first-line treatment are now ongoing (Table 2).

ICI monotherapy activity was not observed in advanced pancreatic cancer patients due to the low immunogenicity and lymphocyte infiltration of tumor lesions [87]. To reverse the immunosuppression of pancreatic cancer, the combination of ICIs with cytotoxic agents, including gemcitabine, irinotecan, 5-FU, and albumin-bound paclitaxel is being evaluated by clinical trials. A randomized phase II trial (NCT02879318) is now ongoing to assess the efficacy of gemcitabine + nab-paclitaxel + durvalumab + tremelimumab versus gemcitabine plus nab-paclitaxel in pancreatic cancer patients. The primary outcome is OS. Although the response of ICIs monotherapy in biliary tract cancer (BTC) is higher than that in pancreatic cancer, the result is also preliminary. A phase Ib trail enrolled 24 advanced BTC patients with PD-L1 expression over $1 \%$. Four patients obtained PR, and four had SD [88]. Clinical trials for NCT03101566 (nivolumab plus gemcitabine/ cisplatin) or NCT03111732 (ipilimumab and pembrolizumab plus CapOX) are now ongoing. Before the publication of these results, chemotherapy is still the major strategy for advanced pancreatic and biliary tract cancer patients.

\section{Future perspectives}

The advantage of ICI combined with conventional treatment, including targeted therapy, chemotherapy, and radiotherapy, has been observed in preclinical research and preliminary clinical trials in GI cancer based on current evidence. However, due to the limited sample size, the treatment efficacy of the combined strategy should be validated by randomized controlled clinical trials before administration in clinical practices.

The toxicities of combined therapy have not been fully assessed. Adverse events of immune checkpoint inhibitors are unique to conventional therapy. Hypothyroidism, hyperthyroidism, increased ALT, pneumonitis, colitis, and hypophysis are the most common grade 3/4 adverse events [35]. In NSCLC, the results of phase III randomized clinical trials showed that the combination of pembrolizumab with chemotherapy did not significantly increase the frequency of grade 3/4 adverse events [82]. In GI cancer, the toxicities of combination strategy should also be evaluated in a large sample size.

To further optimize the benefits of combined therapy of ICIs, some essential factors should be concerned. For ICIs, the endeavor to identify predictive biomarkers had been made. The predictive values of genomic (microsatellite instability, tumor mutation burden, PD-L1 amplification), transcriptomic (RNA signature of immune response), and proteomic (PD-L1 expression) biomarkers have been assessed by perspective clinical trials [89]. In combination therapy, the possible use of present biomarkers to enrich patients who will benefit from combination therapy remains unclear. The optimal dosage of ICIs, sequence of ICIs and conventional therapy, and optimal compatibility of chemotherapy agents or radiotherapy technologies should also be considered in future investigations [85].

With the success of immune checkpoint blockade in the late stage of cancer, its possible application as front-line or even adjuvant therapy to mobilize host anti-tumor immunity at the early stage of disease in immunosuppressive microenvironment has not been induced by multiple therapies or tumor evolution and is preferred to be investigated [90]. Neoadjuvant immunotherapy was assessed in NSCLC. In a pilot study, two preoperative doses of nivolumab were administered in resectable NSCLC patients (stage I, II or IIIA). Twenty out of 22 patients underwent resection. Major pathological response occurred in 9 patients $(45 \%)$. The recurrence-free survival rate after 12 months was $80 \%$ [91]. Clinical trials of ICIs as neoadjuvant or adjuvant treatment for gastro-esophageal cancer are also ongoing (Table 2).

\section{Conclusions}

Immune checkpoint therapy mainly mobilizes host antitumor immune response, which is different from the mechanisms of conventional therapy. With the development of oncologic research, treating cancer patients in their entirety, including tumor cells and the host environment, is critical. Therefore, the combination of immune checkpoint therapy with conventional therapies is promising, and its potential benefit has been observed in several preliminary trials. For GI cancer, investigations of combination therapy are now ongoing, which will provide more valuable clinical evidence to improve patient outcome.

\section{Acknowledgements}

The study was supported by National Natural Science Foundation of China (Nos. 81672327 and 81802319 ) and Program of Shanghai 
Academic/Technology Research Leader (No. 17XD1402600) and Program for Outstanding Medical Academic Leader and Shanghai Municipal Education Commission-Gaofeng Clinical Medicine Grant Support (No. 20161410) and Development Grant for Clinical Trial (No. SHDC12017X06).

\section{Compliance with ethics guidelines}

Chenfei Zhou and Jun Zhang declare that they have no conflicts of interest. This manuscript is a review article and does not involve a research protocol requiring approval by a relevant institutional review board or ethics committee.

Open Access This article is distributed under the terms of the Creative Commons Attribution 4.0 International License (http:// creativecommons.org/licenses/by/4.0/), which permits unrestricted use, distribution, and reproduction in any medium, provided the appropriate credit is given to the original author(s) and the source, and a link is provided to the Creative Commons license, indicating if changes were made.

\section{References}

1. Chen W, Zheng R, Baade PD, Zhang S, Zeng H, Bray F, Jemal A, Yu XQ, He J. Cancer statistics in China, 2015. CA Cancer J Clin 2016; 66(2): 115-132

2. Chen W, Zheng R, Zeng H, Zhang S, He J. Annual report on status of cancer in China, 2011. Chin J Cancer Res 2015; 27(1): 2-12

3. Strong VE, Wu AW, Selby LV, Gonen M, Hsu M, Song KY, Park $\mathrm{CH}$, Coit DG, Ji JF, Brennan MF. Differences in gastric cancer survival between the U.S. and China. J Surg Oncol 2015; 112(1): 31-37

4. Yan S, Li B, Bai ZZ, Wu JQ, Xie DW, Ma YC, Ma XX, Zhao JH, Guo XJ. Clinical epidemiology of gastric cancer in Hehuang valley of China: a 10-year epidemiological study of gastric cancer. World J Gastroenterol 2014; 20(30): 10486-10494

5. Liao Y, Li S, Chen C, He X, Lin F, Wang J, Yang Z, Lan P. Screening for colorectal cancer in Tianhe, Guangzhou: results of combining fecal immunochemical tests and risk factors for selecting patients requiring colonoscopy. Gastroenterol Rep (Oxf) 2018; 6(2): 132-136

6. Lopez A, Harada K, Mizrak Kaya D, Ajani JA. Current therapeutic landscape for advanced gastroesophageal cancers. Ann Transl Med 2018; 6(4): 78

7. Veenstra CM, Krauss JC. Emerging systemic therapies for colorectal cancer. Clin Colon Rectal Surg 2018; 31(3): 179-191

8. Jiménez-Sánchez A, Memon D, Pourpe S, Veeraraghavan H, Li Y, Vargas HA, Gill M B, Park KJ, Zivanovic O, Konner J, Ricca J, Zamarin D, Walther T, Aghajanian C, Wolchok JD, Sala E, Merghoub T, Snyder A, Miller ML. Heterogeneous tumor-immune microenvironments among differentially growing metastases in an ovarian cancer patient. Cell 2017; 170(5): 927-938.e920

9. Lee K, Hwang H, Nam KT. Immune response and the tumor microenvironment: how they communicate to regulate gastric cancer. Gut Liver 2014; 8(2): 131-139
10. Pérez-Ruiz E, Berraondo P. Immunological landscape and clinical management of rectal cancer. Front Immunol 2016; 7: 61

11. Sanchez-Castañón M, Er TK, Bujanda L, Herreros-Villanueva M. Immunotherapy in colorectal cancer: what have we learned so far? Clin Chim Acta 2016; 460: 78-87

12. Le DT, Durham JN, Smith KN, Wang H, Bartlett BR, Aulakh LK, Lu S, Kemberling H, Wilt C, Luber BS, Wong F, Azad NS, Rucki AA, Laheru D, Donehower R, Zaheer A, Fisher GA, Crocenzi TS, Lee JJ, Greten TF, Duffy AG, Ciombor KK, Eyring AD, Lam BH, Joe A, Kang SP, Holdhoff M, Danilova L, Cope L, Meyer C, Zhou S, Goldberg RM, Armstrong DK, Bever KM, Fader AN, Taube J, Housseau F, Spetzler D, Xiao N, Pardoll DM, Papadopoulos N, Kinzler KW, Eshleman JR, Vogelstein B, Anders RA, Diaz LA Jr. Mismatch repair deficiency predicts response of solid tumors to PD1 blockade. Science 2017; 357(6349): 409-413

13. Anderson R, Rapoport BL. Immune dysregulation in cancer patients undergoing immune checkpoint inhibitor treatment and potential predictive strategies for future clinical practice. Front Oncol 2018; 8: 80

14. Robert C, Schachter J, Long GV, Arance A, Grob JJ, Mortier L, Daud A, Carlino MS, McNeil C, Lotem M, Larkin J, Lorigan P, Neyns B, Blank CU, Hamid O, Mateus C, Shapira-Frommer R, Kosh M, Zhou H, Ibrahim N, Ebbinghaus S, Ribas A; the KEYNOTE-006 investigators. Pembrolizumab versus ipilimumab in advanced melanoma. N Engl J Med 2015; 372(26): 2521-2532

15. Borghaei H, Paz-Ares L, Horn L, Spigel DR, Steins M, Ready NE, Chow LQ, Vokes EE, Felip E, Holgado E, Barlesi F, Kohlhaufl M, Arrieta O, Burgio MA, Fayette J, Lena H, Poddubskaya E, Gerber DE, Gettinger SN, Rudin CM, Rizvi N, Crino L, Blumenschein GR Jr, Antonia SJ, Dorange C, Harbison CT, Graf Finckenstein F, Brahmer JR. Nivolumab versus docetaxel in advanced nonsquamous non-small-cell lung cancer. N Engl J Med 2015; 373(17): $1627-1639$

16. Overman MJ, McDermott R, Leach JL, Lonardi S, Lenz HJ, Morse MA, Desai J, Hill A, Axelson M, Moss RA, Goldberg MV, Cao ZA, Ledeine JM, Maglinte GA, Kopetz S, Andre T. Nivolumab in patients with metastatic DNA mismatch repair-deficient or microsatellite instability-high colorectal cancer (CheckMate 142): an open-label, multicentre, phase 2 study. Lancet Oncol 2017; 18(9): 1182-1191

17. Fuchs CS, Doi T, Jang RW, Muro K, Satoh T, Machado M, Sun W, Jalal SI, Shah MA, Metges JP, Garrido M, Golan T, Mandala M, Wainberg ZA, Catenacci DV, Ohtsu A, Shitara K, Geva R, Bleeker J, Ko AH, Ku G, Philip P, Enzinger PC, Bang YJ, Levitan D, Wang J, Rosales M, Dalal RP, Yoon HH. Safety and efficacy of pembrolizumab monotherapy in patients with previously treated advanced gastric and gastroesophageal junction cancer: Phase 2 Clinical KEYNOTE-059 Trial. JAMA Oncol 2018; 4(5): e180013

18. Kang YK, Boku N, Satoh T, Ryu MH, Chao Y, Kato K, Chung HC, Chen JS, Muro K, Kang WK, Yeh KH, Yoshikawa T, Oh SC, Bai LY, Tamura T, Lee KW, Hamamoto Y, Kim JG, Chin K, Oh DY, Minashi K, Cho JY, Tsuda M, Chen LT. Nivolumab in patients with advanced gastric or gastro-oesophageal junction cancer refractory to, or intolerant of, at least two previous chemotherapy regimens (ONO-4538-12, ATTRACTION-2): a randomised, double-blind, placebo-controlled, phase 3 trial. Lancet 2017; 390(10111): 24612471 
19. Kudo T, Hamamoto Y, Kato K, Ura T, Kojima T, Tsushima T, Hironaka S, Hara H, Satoh T, Iwasa S, Muro K, Yasui H, Minashi K, Yamaguchi K, Ohtsu A, Doki Y, Kitagawa Y. Nivolumab treatment for oesophageal squamous-cell carcinoma: an open-label, multicentre, phase 2 trial. Lancet Oncol 2017; 18(5): 631-639

20. Gotwals P, Cameron S, Cipolletta D, Cremasco V, Crystal A, Hewes B, Mueller B, Quaratino S, Sabatos-Peyton C, Petruzzelli L, Engelman JA, Dranoff G. Prospects for combining targeted and conventional cancer therapy with immunotherapy. Nat Rev Cancer 2017; 17(5): 286-301

21. Blair AB, Murphy A. Immunotherapy as a treatment for biliary tract cancers: a review of approaches with an eye to the future. Curr Probl Cancer 2018; 42(1): 49-58

22. Lee V, Murphy A, Le DT, Diaz LA Jr. Mismatch repair deficiency and response to immune checkpoint blockade. Oncologist 2016; 21 (10): 1200-1211

23. Ciombor KK, Bekaii-Saab T. A comprehensive review of sequencing and combination strategies of targeted agents in metastatic colorectal cancer. Oncologist 2018; 23(1): 25-34

24. Sharma P, Allison JP. The future of immune checkpoint therapy. Science 2015; 348(6230): 56-61

25. Chen DS, Mellman I. Oncology meets immunology: the cancerimmunity cycle. Immunity $2013 ; 39(1)$ : $1-10$

26. Kim R, Emi M, Tanabe K. Cancer immunoediting from immune surveillance to immune escape. Immunology 2007; 121(1): 1-14

27. Beatty GL, Gladney WL. Immune escape mechanisms as a guide for cancer immunotherapy. Clin Cancer Res 2015; 21(4): 687-692

28. Muenst S, Laubli H, Soysal SD, Zippelius A, Tzankov A, Hoeller S. The immune system and cancer evasion strategies: therapeutic concepts. J Intern Med 2016; 279(6): 541-562

29. Mariathasan S, Turley SJ, Nickles D, Castiglioni A, Yuen K, Wang Y, Kadel EE III, Koeppen H, Astarita JL, Cubas R, Jhunjhunwala S, Banchereau R, Yang Y, Guan Y, Chalouni C, Ziai J, Senbabaoglu Y, Santoro S, Sheinson D, Hung J, Giltnane JM, Pierce AA, Mesh K, Lianoglou S, Riegler J, Carano R A D, Eriksson P, Hoglund M, Somarriba L, Halligan DL, van der Heijden MS, Loriot Y, Rosenberg JE, Fong L, Mellman I, Chen DS, Green M, Derleth C, Fine GD, Hegde PS, Bourgon R, Powles T. TGF $\beta$ attenuates tumour response to PD-L1 blockade by contributing to exclusion of T cells. Nature 2018; 554(7693): 544-548

30. Tauriello DVF, Palomo-Ponce S, Stork D, Berenguer-Llergo A, Badia-Ramentol J, Iglesias M, Sevillano M, Ibiza S, Canellas A, Hernando-Momblona X, Byrom D, Matarin JA, Calon A, Rivas EI, Nebreda AR, Riera A, Attolini CS, Batlle E. TGF $\beta$ drives immune evasion in genetically reconstituted colon cancer metastasis. Nature 2018; 554(7693): 538-543

31. Ward-Hartstonge KA, Kemp RA. Regulatory T-cell heterogeneity and the cancer immune response. Clin Transl Immunology 2017; 6 (9): e154

32. Sun J, Zhang Y, Yang M, Zhang Y, Xie Q, Li Z, Dong Z, Yang Y, Deng B, Feng A, Hu W, Mao H, Qu X. Hypoxia induces T-cell apoptosis by inhibiting chemokine $\mathrm{C}$ receptor 7 expression: the role of adenosine receptor A(2). Cell Mol Immunol 2010; 7(1): 77-82

33. Rudd CE, Taylor A, Schneider H. CD28 and CTLA-4 coreceptor expression and signal transduction. Immunol Rev 2009; 229(1): 12 26

34. Pardoll DM. The blockade of immune checkpoints in cancer immunotherapy. Nat Rev Cancer 2012; 12(4): 252-264

35. Boutros C, Tarhini A, Routier E, Lambotte O, Ladurie FL, Carbonnel F, Izzeddine H, Marabelle A, Champiat S, Berdelou A, Lanoy E, Texier M, Libenciuc C, Eggermont AM, Soria JC, Mateus C, Robert C. Safety profiles of anti-CTLA-4 and anti-PD-1 antibodies alone and in combination. Nat Rev Clin Oncol 2016; 13(8): 473-486

36. Maj E, Papiernik D, Wietrzyk J. Antiangiogenic cancer treatment: the great discovery and greater complexity. Int J Oncol 2016; 49(5): 1773-1784

37. Wallin JJ, Bendell JC, Funke R, Sznol M, Korski K, Jones S, Hernandez G, Mier J, He X, Hodi FS, Denker M, Leveque V, Canamero M, Babitski G, Koeppen H, Ziai J, Sharma N, Gaire F, Chen DS, Waterkamp D, Hegde PS, McDermott DF. Atezolizumab in combination with bevacizumab enhances antigen-specific T-cell migration in metastatic renal cell carcinoma. Nat Commun 2016; 7 (1): 12624

38. Fukumura D, Kloepper J, Amoozgar Z, Duda DG, Jain RK. Enhancing cancer immunotherapy using antiangiogenics: opportunities and challenges. Nat Rev Clin Oncol 2018; 15(5): 325-340

39. Ott PA, Hodi FS, Buchbinder EI. Inhibition of immune checkpoints and vascular endothelial growth factor as combination therapy for metastatic melanoma: an overview of rationale, preclinical evidence, and initial clinical data. Front Oncol 2015; 5: 202

40. Ghiringhelli F, Puig PE, Roux S, Parcellier A, Schmitt E, Solary E, Kroemer G, Martin F, Chauffert B, Zitvogel L. Tumor cells convert immature myeloid dendritic cells into TGF- $\beta$-secreting cells inducing $\mathrm{CD} 4{ }^{+} \mathrm{CD} 25^{+}$regulatory $\mathrm{T}$ cell proliferation. J Exp Med 2005; 202(7): 919-929

41. Terme M, Pernot S, Marcheteau E, Sandoval F, Benhamouda N, Colussi O, Dubreuil O, Carpentier AF, Tartour E, Taieb J. VEGFAVEGFR pathway blockade inhibits tumor-induced regulatory T-cell proliferation in colorectal cancer. Cancer Res 2013; 73(2): 539-549

42. Gabrilovich D, Ishida T, Oyama T, Ran S, Kravtsov V, Nadaf S, Carbone DP. Vascular endothelial growth factor inhibits the development of dendritic cells and dramatically affects the differentiation of multiple hematopoietic lineages in vivo. Blood 1998; 92(11): 4150-4166

43. Dikov MM, Ohm JE, Ray N, Tchekneva EE, Burlison J, Moghanaki D, Nadaf S, Carbone DP. Differential roles of vascular endothelial growth factor receptors 1 and 2 in dendritic cell differentiation. J Immunol 2005; 174(1): 215-222

44. Osada T, Chong G, Tansik R, Hong T, Spector N, Kumar R, Hurwitz HI, Dev I, Nixon AB, Lyerly HK, Clay T, Morse MA. The effect of anti-VEGF therapy on immature myeloid cell and dendritic cells in cancer patients. Cancer Immunol Immunother 2008; 57(8): $1115-1124$

45. Huang Y, Goel S, Duda DG, Fukumura D, Jain RK. Vascular normalization as an emerging strategy to enhance cancer immunotherapy. Cancer Res 2013; 73(10): 2943-2948

46. Shrimali RK, Yu Z, Theoret MR, Chinnasamy D, Restifo NP, Rosenberg SA. Antiangiogenic agents can increase lymphocyte infiltration into tumor and enhance the effectiveness of adoptive immunotherapy of cancer. Cancer Res 2010; 70(15): 6171-6180

47. Strickler JH, Hurwitz HI. Bevacizumab-based therapies in the firstline treatment of metastatic colorectal cancer. Oncologist 2012; 17 (4): 513-524 
48. Li J, Qin S, Xu R, Yau TC, Ma B, Pan H, Xu J, Bai Y, Chi Y, Wang L, Yeh KH, Bi F, Cheng Y, Le AT, Lin JK, Liu T, Ma D, Kappeler C, Kalmus J, Kim TW; the CONCUR Investigators. Regorafenib plus best supportive care versus placebo plus best supportive care in Asian patients with previously treated metastatic colorectal cancer (CONCUR): a randomised, double-blind, placebo-controlled, phase 3 trial. Lancet Oncol 2015; 16(6): 619-629

49. Llovet JM, Ricci S, Mazzaferro V, Hilgard P, Gane E, Blanc JF, de Oliveira AC, Santoro A, Raoul JL, Forner A, Schwartz M, Porta C, Zeuzem S, Bolondi L, Greten TF, Galle PR, Seitz JF, Borbath I, Haussinger D, Giannaris T, Shan M, Moscovici M, Voliotis D, Bruix $\mathrm{J}$; the SHARP Investigators Study Group. Sorafenib in advanced hepatocellular carcinoma. N Engl J Med 2008; 359(4): 378-390

50. Llovet JM, Montal R, Sia D, Finn RS. Molecular therapies and precision medicine for hepatocellular carcinoma. Nat Rev Clin Oncol 2018; 15(10): 599-616

51. Fuchs CS, Tomasek J, Yong CJ, Dumitru F, Passalacqua R, Goswami C, Safran H, Dos Santos LV, Aprile G, Ferry DR, Melichar B, Tehfe M, Topuzov E, Zalcberg JR, Chau I, Campbell W, Sivanandan C, Pikiel J, Koshiji M, Hsu Y, Liepa AM, Gao L, Schwartz JD, Tabernero J; the REGARD Trial Investigators. Ramucirumab monotherapy for previously treated advanced gastric or gastro-oesophageal junction adenocarcinoma (REGARD): an international, randomised, multicentre, placebo-controlled, phase 3 trial. Lancet 2014; 383(9911): 31-39

52. Yasuda S, Sho M, Yamato I, Yoshiji H, Wakatsuki K, Nishiwada S, Yagita H, Nakajima Y. Simultaneous blockade of programmed death 1 and vascular endothelial growth factor receptor 2 (VEGFR2) induces synergistic anti-tumour effect in vivo. Clin Exp Immunol 2013; 172(3): 500-506

53. Jain RK. Normalization of tumor vasculature: an emerging concept in antiangiogenic therapy. Science 2005; 307(5706): 58-62

54. Hochster HS, Bendell JC, Cleary JM, Foster P, Zhang W, He X, Hernandez G, lizuka K. Efficacy and safety of atezolizumab (atezo) and bevacizumab (bev) in a phase Ib study of microsatellite instability (MSI)-high metastatic colorectal cancer (mCRC). J Clin Oncol 2017; 35(4_suppl): 673

55. Wallin J, Pishvaian MJ, Hernandez G, Yadav M, Jhunjhunwala S, Delamarre L, He X, Powderly J, Lieu C, Eckhardt SG, Hurwitz H, Hochster HS, Murphy J, Leveque V, Cha E, Funke R, Waterkamp D, Hegde P, Bendell J. Clinical activity and immune correlates from a phase Ib study evaluating atezolizumab (anti-PDL1) in combination with FOLFOX and bevacizumab (anti-VEGF) in metastatic colorectal carcinoma. Cancer Res, 2016, 76(14_suppl): 2651

56. Saltz LB, Clarke S, Diaz-Rubio E, Scheithauer W, Figer A, Wong R, Koski S, Lichinitser M, Yang TS, Rivera F, Couture F, Sirzen F, Cassidy J. Bevacizumab in combination with oxaliplatin-based chemotherapy as first-line therapy in metastatic colorectal cancer: a randomized phase III study. J Clin Oncol 2008; 26(12): 2013-2019

57. Smyth E, Thuss-Patience PC. Immune checkpoint inhibition in gastro-oesophageal cancer. Oncol Res Treat 2018; 41(5): 272-280

58. Bang YJ, Golan T, Lin CC, Kang YK, Wainberg Z, Wasserstrom H, Jin J, Mi G, McNeely S, Laing N, Goff LW, Fu S. Interim safety and clinical activity in patients (pts) with locally advanced and unresectable or metastatic gastric or gastroesophageal junction $(\mathrm{G} /$ GEJ) adenocarcinoma from a multicohort phase I study of ramucirumab (R) plus durvalumab (D). J Clin Oncol 2018; 36 (4_suppl): 92

59. Ikeda M, Sung M W, Kudo M. A phase 1b trial of lenvatinib (LEN) plus pembrolizumab (PEM) in patients (pts) with unresectable hepatocellular carcinoma (uHCC). J Clin Oncol 2018; 36(suppl): abstr 4076

60. Stein S, Pishvaian M J, Lee M S. Safety and clinical activity of 1L atezolizumab + bevacizumab in a phase $\mathrm{Ib}$ study in hepatocellular carcinoma (HCC). J Clin Oncol 2018; 36(suppl): abstr 4074

61. Corraliza-Gorjón I, Somovilla-Crespo B, Santamaria S, GarciaSanz JA, Kremer L. New strategies using antibody combinations to increase cancer treatment effectiveness. Front Immunol 2017; 8: 1804

62. Ferris RL, Lenz HJ, Trotta AM, Garcia-Foncillas J, Schulten J, Audhuy F, Merlano M, Milano G. Rationale for combination of therapeutic antibodies targeting tumor cells and immune checkpoint receptors: harnessing innate and adaptive immunity through IgG1 isotype immune effector stimulation. Cancer Treat Rev 2018; 63: $48-60$

63. Inoue $\mathrm{Y}$, Hazama S, Suzuki N, Tokumitsu Y, Kanekiyo S, Tomochika S, Tsunedomi R, Tokuhisa Y, Iida M, Sakamoto K, Takeda S, Ueno T, Yoshino S, Nagano H. Cetuximab strongly enhances immune cell infiltration into liver metastatic sites in colorectal cancer. Cancer Sci 2017; 108(3): 455-460

64. Chen S, Li X, Chen R, Yin M, Zheng Q. Cetuximab intensifies the ADCC activity of adoptive NK cells in a nude mouse colorectal cancer xenograft model. Oncol Lett 2016; 12(3): 1868-1876

65. Jie HB, Schuler PJ, Lee SC, Srivastava RM, Argiris A, Ferrone S, Whiteside TL, Ferris RL. CTLA-4(+) regulatory t cells increased in cetuximab-treated head and neck cancer patients suppress NK cell cytotoxicity and correlate with poor prognosis. Cancer Res 2015; 75 (11): 2200-2210

66. Jie HB, Srivastava RM, Argiris A, Bauman JE, Kane LP, Ferris RL. Increased PD-1(+) and TIM-3(+) TILs during cetuximab therapy inversely correlate with response in head and neck cancer patients. Cancer Immunol Res 2017; 5(5): 408-416

67. Inoue $\mathrm{H}$, Horii R, Ito $\mathrm{Y}$, Iwase $\mathrm{T}$, Ohno S, Akiyama F. Tumorinfiltrating lymphocytes affect the efficacy of trastuzumab-based treatment in human epidermal growth factor receptor 2-positive breast cancer. Breast Cancer 2018; 25(3): 268-274

68. Chaganty BKR, Qiu S, Gest A, Lu Y, Ivan C, Calin GA, Weiner LM, Fan Z. Trastuzumab upregulates PD-L1 as a potential mechanism of trastuzumab resistance through engagement of immune effector cells and stimulation of IFN $\gamma$ secretion. Cancer Lett 2018; 430: 47-56

69. Catenacci D V, Park H, Uronis H E, Kang Y, Lacy J, Enzinger P C, Park S H, Lee K W. Margetuximab plus pembrolizumab in ERBB2amplified PD-L1 + gastroesophageal adenocarcinoma post trastuzumab. J Clin Oncol 2018; 36(suppl): abstr 4030

70. Robert L, Ribas A, Hu-Lieskovan S. Combining targeted therapy with immunotherapy. Can $1+1$ equal more than 2 ? Semin Immunol 2016; 28(1): 73-80

71. Patel SA, Minn AJ. Combination cancer therapy with immune checkpoint blockade: mechanisms and strategies. Immunity 2018; 48(3): 417-433

72. Azad N S, Shirai K, McRee A J, Opyrchal M, Johnson D B, Ordentlich P, Brouwer S, Sankoh S, Schmidt E V, Meyers M L, Johnson M L. ENCORE 601: a phase 2 study of entinostat in 
combinationwith pembrolizumab in patients with microsatellite stable metastatic colorectal cancer. J Clin Oncol 2018; 36(suppl): abstr 3557

73. Bendell J, Kim TW, Goh B, Wallin J, Oh DY, Han SW, Lee C, Hellmann MD, Desai J, Lewin JH, Solomon B, Chow QM, Miller W, Gainor J, Flaherty K, Infante J, Das-Thakur M, Foster P, Cha E, Bang YJ. Clinical activity and safety of cobimetinib (cobi) and atezolizumab in colorectal cancer (CRC). J Clin Oncol 2016; 34 (5_suppl): 3502

74. Bendell J, Ciardiello F, Tabernero J, Tebbutt N, Eng C, Bartolomeo M Di, Falcone A, Fakih M, Kozloff M, Segal N, Sobrero A, Shi Y, Roberts L, Yan Y, Chang I, Uyei A, Kim T. Efficacy and safety results from IMblaze370, a randomised phase III study comparing atezolizumab1cobimetinib and atezolizumab monotherapy vs. regorafenib in chemotherapy-refractory metastatic colorectal cancer. Ann Oncol 2018; 29(suppl_5): LBA-004

75. Sharma P, Allison JP. Immune checkpoint targeting in cancer therapy: toward combination strategies with curative potential. Cell 2015; 161(2): 205-214

76. Reits EA, Hodge JW, Herberts CA, Groothuis TA, Chakraborty M, Wansley EK, Camphausen K, Luiten RM, de Ru AH, Neijssen J, Griekspoor A, Mesman E, Verreck FA, Spits H, Schlom J, van Veelen P, Neefjes JJ. Radiation modulates the peptide repertoire, enhances MHC class I expression, and induces successful antitumor immunotherapy. J Exp Med 2006; 203(5): 1259-1271

77. Young KH, Baird JR, Savage T, Cottam B, Friedman D, Bambina S, Messenheimer DJ, Fox B, Newell P, Bahjat KS, Gough MJ, Crittenden MR. Optimizing timing of immunotherapy improves control of tumors by hypofractionated radiation therapy. PLoS One 2016; 11(6): e0157164

78. Demaria S, Coleman CN, Formenti SC. Radiotherapy: changing the game in immunotherapy. Trends Cancer 2016; 2(6): 286-294

79. Pico de Coaña Y, Choudhury A, Kiessling R. Checkpoint blockade for cancer therapy: revitalizing a suppressed immune system. Trends Mol Med 2015; 21(8): 482-491

80. Xu X, Huang Z, Zheng L, Fan Y. The efficacy and safety of anti-PD1/PD-L1 antibodies combined with chemotherapy or CTLA4 antibody as a first-line treatment for advanced lung cancer. Int $\mathrm{J}$ Cancer 2018; 142(11): 2344-2354

81. Blumenthal GM, Zhang L, Zhang H, Kazandjian D, Khozin S, Tang S, Goldberg K, Sridhara R, Keegan P, Pazdur R. Milestone analyses of immune checkpoint inhibitors, targeted therapy, and conventional therapy in metastatic non-small cell lung cancer trials: a metaanalysis. JAMA Oncol 2017; 3(8): e171029

82. Gandhi L, Rodriguez-Abreu D, Gadgeel S, Esteban E, Felip E, De Angelis F, Domine M, Clingan P, Hochmair MJ, Powell SF, Cheng
SY, Bischoff HG, Peled N, Grossi F, Jennens RR, Reck M, Hui R, Garon EB, Boyer M, Rubio-Viqueira B, Novello S, Kurata T, Gray JE, Vida J, Wei Z, Yang J, Raftopoulos H, Pietanza MC, Garassino MC; the KEYNOTE-189 Investigators. Pembrolizumab plus chemotherapy in metastatic non-small-cell lung cancer. N Engl J Med 2018; 378(22): 2078-2092

83. Bang YJ, Muro K, Fuchs C, Golan T, Geva R, Hara H, Jalal SI, Borg C, Doi T, Wainberg Z, Wang JD, Koshiji M, Dalal R, Chung HC. KEYNOTE-059 cohort 2: safety and efficacy of pembrolizumab (pembro) plus 5-fluorouracil (5-FU) and cisplatin for first-line (1L) treatment of advanced gastric cancer. J Clin Oncol 2017; 35 (15_suppl): 4012

84. Herrera FG, Bourhis J, Coukos G. Radiotherapy combination opportunities leveraging immunity for the next oncology practice. CA Cancer J Clin 2017; 67(1): 65-85

85. Beg MS, Meyer J. Developing rational combinations of immune checkpoint inhibitors and radiation therapy for gastrointestinal cancers. J Gastrointest Oncol 2018; 9(1): 225-230

86. Fiorica F, Belluomini L, Stefanelli A, Santini A, Urbini B, Giorgi C, Frassoldati A. Immune checkpoint inhibitor nivolumab and radiotherapy in pretreated lung cancer patients: efficacy and safety of combination. Am J Clin Oncol 2018 Jan 31. [Epub ahead of print] doi: 10.1097/COC.0000000000000428

87. Hilmi M, Bartholin L, Neuzillet C. Immune therapies in pancreatic ductal adenocarcinoma: where are we now? World J Gastroenterol 2018; 24(20): 2137-2151

88. Bang YJ, Doi T, De Broud F, Piha-Paul S, Hollebecque A, Razak AR. Safety and efficacy of pembrolizumab (MK-3475) in patients (pts) with advanced biliary tract cancer: interim results of KEYNOTE-028. Eur J Cancer 2015; 51(3): s112

89. Weinberg BA, Xiu J, Hwang JJ, Shields AF, Salem ME, Marshall JL. Immuno-oncology biomarkers for gastric and gastroesophageal junction adenocarcinoma: why PD-L1 testing may not be enough. Oncologist 2018; 23(10): 1171-1177

90. Deslypere G, Gullentops D, Wauters E, Vansteenkiste J. Immunotherapy in non-metastatic non-small cell lung cancer: can the benefits of stage IV therapy be translated into earlier stages? Ther Adv Med Oncol 2018; 10: 1758835918772810

91. Forde PM, Chaft JE, Smith KN, Anagnostou V, Cottrell TR, Hellmann MD, Zahurak M, Yang SC, Jones DR, Broderick S, Battafarano RJ, Velez MJ, Rekhtman N, Olah Z, Naidoo J, Marrone KA, Verde F, Guo H, Zhang J, Caushi JX, Chan HY, Sidhom JW, Scharpf RB, White J, Gabrielson E, Wang H, Rosner GL, Rusch V, Wolchok JD, Merghoub T, Taube JM, Velculescu VE, Topalian SL, Brahmer JR, Pardoll DM. Neoadjuvant PD-1 blockade in resectable lung cancer. N Engl J Med 2018; 378(21): 1976-1986 